\title{
Man Versus Nature: Ernest Hemingway's Irony in the Old Man and the Sea
}

\author{
S. G. Mohanraj \\ Department of English, Kumaraguru College of Technology, Coimbatore, India
}

\begin{abstract}
Ernest Hemingway's words that "Man is not much beside the great birds and beasts" (66) in the novel The Old Man and the Sea showcase the big fissure that can be found in the relationship between man and nature. The lines, "thank God, they are not as intelligent as we who kill them; although they are more noble and more able," (Hemingway 61) speaks the rest. It is prominent that ego of man destroys the entire natural world, and this message has been clearly conveyed by Ernest Hemingway on many occasions in this novel. The statement that "A man can be destroyed but not defeated" (Hemingway 102) stands as an irony in this novel since the plot clearly depicts the defeat of the old man Santiago towards the conclusion. An analysis of the ecological underpinnings in the novel and the relationship between man and nature from the author's perspective best reflects the irony.
\end{abstract}

KEY WORDS: ECOCRITICISM, NATURE WRITING, ECOLOGY, ENVIRONMENT, ECOSYSTEM.

\section{INTRODUCTION}

Critics and "scholars throughout the humanities are finding ways to add an environmental dimension to their respective disciplines" (Glotfelty xxi). The significance of emerging ecocriticism is well understood by most of the people. Even the psychologists have started analysing the relationship between the mental health and the surrounding environment in which people live. Ecocritics are slowly marching ahead to study the environmental conditions in which the author lives or lived to understand better the influence of nature in his imagination. Glen A. Love "recommends that revaluing nature-oriented literature can help redirect us from egoconsciousness to "eco-consciousness"” (Glotfelty xxx). "Nature writing boasts a rich past, a vibrant present, and a promising future" (Glotfelty xxiii). Deep ecologists voice for a complete return to nature, which may not be possible, but creating awareness about the substance of nature is always an achievable task. An attempt of reading the text of literature from an ecocentric perspective has

Biosc Biotech Res Comm P-ISSN: 0974-6455 E-ISSN: 2321-4007
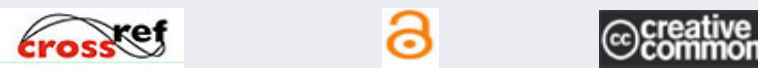

Identifiers and Pagination

Article Information

Year: 2021 Vol: 14 No (8) Special Issue

Received: $28^{\text {th }}$ May 2021

Pages: 173-177

Accepted after revision: $19^{\text {th }}$ July 2021

This is an open access article under Creative

Commons License Attribn 4.0 Intl (CC-BY).

DOI: $h t t p: / / d x$.doi.org/10.21786/bbrc/14.8.40 been done on The Old Man and the Sea to illustrate the accountability of such an effort.

The Old Man and the Sea by Ernest Hemingway contains a number of natural descriptions and it has a close relationship between the naturally existing climax ecosystems and the interference of mankind into it. The story of this novel takes place far away from an ordinary dwelling place of human race. Majority of incidents take place far inside the sea. Hence, this paves way for abundant natural descriptions throughout the novel and these descriptions lead to numerous statements in relation to the basic tenets of ecocriticism.

Santiago, the protagonist of the novel, states that "Man is not much beside the great birds and beasts" (Hemingway 66). These words of the old man throw light on the big fissure that can be found in the relationship between man and nature. The lines, "thank God, they are not as intelligent as we who kill them; although they are more noble and more able," (Hemingway 61) indicate that nature is nobler than man even without intelligence and the intellectual human beings utilize their intelligence only in destroying nature. It is only the ego of man that destroys the natural world and this has been portrayed by Hemingway stating that "But I will show him what a man can do and what a man endures" (64). Earlier, people were praying to God to save their own kind, but now they have started to pray to God to help them dominate nature. This can be well understood through the example 
that Santiago prays to Christ to help him hook the giant marlin. One can even say that human community destroys nature knowingly and purposefully. It is their duty to prevent the destruction of nature and realize that it is a shameful act to destroy nature as Hemingway puts it, "Besides I believe it is a sin" (104).

Human Interference Into The Marine Life: Only an ecocritical reading of a text will bring out the essential greatness of nature. Santiago calls the giant marlin as his brother and wishes to feed it at one point of time, which indicates that man is also a part of nature. He also adds that the fish is his friend too. He admires the great dignity of the marlin and states that he has never seen a fish like it and no human being is worthy of eating it. This shows that the intensity of relationship is more important than duration. The relationship between man and nature should thus be intense to preserve nature from extinction. Hemingway tries to dignify nature through these words of the old man. He also adds that nature is the noblest thing with the lines "Never have I seen a greater, or more beautiful, or a calmer or more noble thing than you" (Hemingway 92). There are many references to the interference of man into the natural world in the novel.

It can be mentioned that the whole theme of this novel is about the interference of an old man into the aquatic ecosystem. Santiago decides to work out at a place where he can find more fish when he starts his sail. There is also a mention more frequently in this novel that he is not able to see any trace of land nearby indicating that he went too far into the ocean disturbing its natural eco-cycle. There is a sentence stating that "An aeroplane passed overhead on its course to Miami and he watched its shadow scaring up the schools of flying fish" (Hemingway 69). This indicates that even an aeroplane that is going up high in the air disturbs an ecosystem that prevails farther to it. In the climax part of the novel, one can notice that Santiago kills numerous sharks that approached the skiff to feed on the dead marlin. This resembles the fact that man disturbs an ecosystem and destroys nature for his own beneficiary.

Divergenge Of Themes: For instance, the theme of the novel can be presented in two different ways. The first way is to argue in the traditional manner that this novel portrays the struggle of an old Cuban fisherman to fish a marlin. The story also pictures the nobility of the old man, Santiago, who is standing at the edge of his life setting standards to his fellowmen and serves as an example for all the fishermen. The very behaviour of Santiago signifies his nobility, and his confidence and belief about his ability to achieve lifts him to peaks. The author expresses Santiago's determination strongly through the words "But man is not made for defeat,' he said. 'A man can be destroyed but not defeated"' (Hemingway 102). The struggle of the old man with the giant marlin also intensifies the character of Santiago. Fight between two unequal forces serves as a great source of inspiration for this novel.
The same novel can be pictured in one another way from an ecocritical point of view. The essence of the novel insists the fact that man is only a part of biotic community and in no way, he can step into other ecosystems. This theme has been strongly portrayed by Ernest Hemingway by providing an exotic end to the novel. The point that Santiago interfered into the aquatic ecosystem of the ocean has been stressed by the author in a number of places. Santiago himself repeatedly says that he has committed a mistake by getting too deep into the sea. One another fact that marlin belongs to the aquatic ecosystem and man cannot possess the marlin is stressed by the character of sharks. The Mako sharks feed on the giant marlin in spite of the great struggle from Santiago and prove that marlin is their possession, and no one can take away their ownership in the sea. Thus, Hemingway confirms that mother nature is the supreme power and humans are only mere participants in an existing ecosystem.

Climax Ecosystem: An ecocritical reading is significant since it portrays the supremacy of nature. It becomes equally important to know about the concept of climax ecosystems to understand the ecocritical theories better. Basically, the existence of living creatures among the nonliving things with a perfect balance and interdependence within a particular area is called as an ecosystem. The natural ecosystem is represented as a complex web of interconnected elements with the biological functioning of each creature dependent on the biological functioning of the other. The equilibrium between all the elements in an ecosystem will be maintained throughout. For example, an ecosystem in a pond can be explained for better understanding. There will be always a balance between the living creatures that live in an ecosystem.

This particular aquatic ecosystem starts with the small bacteria and algae that live in a pond which will serve as food for smaller organisms. These smaller organisms, in turn, will be the prey for small fish, which will feed the bigger ones. The carcass of the bigger fish will decay and provide nourishment for the bacteria and other microorganisms. The plants also serve as food for the bacteria and other living organisms in the pond which, in turn, may gain nutrients from the animal waste. This equilibrium persists in all ecosystems until it is interfered by any external force, the entry of which can collapse the whole eco-cycle. This interference may lead to the extinction of the entire ecosystem, which implies the extinction of a natural phenomenon.

A climax ecosystem is a type of ecosystem in which the diversified living and non-living things are present with a correct balance between them. Climax communities of plants and animals are extremely diverse and complicated groupings of living things which exist in a relatively balanced state with one another and with their nonliving environment. A climax ecosystem is much more complicated than any human social organization, if only because it integrates the diverse needs and activities of a very large number of different species. (Meeker 162). 
Survival Of Single Species Versus Overall Survival: In the human community, the significance is given only to the human race and only anthropocentricism plays a vital role, whereas in the climax ecosystem, the significance is uniformly distributed to all the participants in the ecosystem. Only this type of ecosystem stresses that all the participants, i.e., the minor elements as well as the major elements, are related to each other and together form an interdependent biological environment. The most important aspect of the climax ecosystem is that the survival of one species is dependent upon the other and no individual species can survive without the existence of other species. In the climax ecosystem, the safety for each individual element will be less as they may fall a prey to other elements, but the equilibrium will be maintained within the ecosystem and it will prevent the extinction of species from the natural world.

"The welfare of individuals is generally subordinated to the welfare of the group" (Meeker 162). All the organisms in the biosphere have an equal right to live and none can pose a threat on the wellbeing of the other. Only survival can be the privilege of an organism including man and in no way can it destroy the other opponent forces for its existence, which may be a threat for natural ecosystems and may result in destruction of nature. All entities in the ecosphere have equal central value. Therefore, nonhuman and human are not only interdependent but also equal within the biological community. A climax ecosystem in its complexity is easily beyond human comprehension. Humans think that they are superior and all other natural ecosystems are simpler in their form and can never reach their complexity, but the reality is that only human life is much simpler than the natural ecosystems.

In recent years, one can find that the approach of human beings towards the natural setting has considerably changed. The complex nature of animal behavior has been explored by the human community. The presentday television channels which report the natural world and the behavioral patterns of animals and birds serve as evidence for this. The ornithologists wonder about the peculiar behavior of birds. It is still unclear how these small birds cross continents for migration and return to their native place at the end of a particular season. The zoologists admire at the ability of the animals and the care they show in nursing the young ones. It has been a big question as to how these animals and birds are able to sense the needs of others and how they are able to communicate with one another from a fairly long distance. The adaptive mechanism of animals is also enormous, and unlike human community, they can adapt themselves to most of the natural climax ecosystems.

\footnotetext{
"We are slowly beginning to realize that we have grossly underestimated the animals" (Meeker 164). In The Old Man and the Sea, the climax ecosystem that has been portrayed is aquatic in the form of a great ocean, which is huge and there dwell millions of participants. A detailed description of many of its participants has been given by Ernest Hemingway through the inner voice of Santiago, the old man. This text also explains the interrelationship
}

between the participants in an ecosystem and the interference of man affecting the whole eco-cycle. The participants of the aquatic ecosystem in this novel include man-of-war bird, flying fish, tuna, marlin, broadbill, shark, dolphin, yellow Gulf weed, Sargasso weed, agua mala, warbler, hawks, bonito, shrimp, squid, wild ducks, sucking fish, and many more.

Interdependence And Existence: Interdependence and existence of various creatures and plants within the aquatic ecosystem is portrayed in this novel in various occasions. When the old man enters the sea for fishing, there is a note stating that he crosses the deeper part of the sea where all sorts of fish dwell because of existing current. One can sort fish like bait fish, flying fish, squid, and shrimp in that particular region of the sea. Santiago loves to see the sea turtles eating the agua mala which are in the form of bubbles. The old man, after hooking the great marlin, prays to God to prevent sharks nearing the skiff. He also states, "If sharks come, God pity him (marlin) and me" (Hemingway 67). This statement of the old man reflects that the sharks will feed on the marlin and thus the existence of sharks depends upon the existence of other types of fish like marlin. At one point of time, the old man sees numerous flying fish in a specific area and states that definitely there should be a dolphin pointing out the interdependence of the flying fish and the dolphin that dolphin will feed on flying fish. The old man, on his return journey, hooks yellow Gulf weed in order to collect the tiny shrimps in it and he could find more than a dozen. This description shows that Santiago is aware of the fact that shrimps feed on the yellow Gulf weed.

There is a mention of some plants that exist in an aquatic ecosystem in this text. The existence of yellow Gulf weed in the sea is explained in numerous places. In some places, phosphorescence of the Gulf weed has been explained. Plankton also finds its way in some places of the text reminding that it is also an entity in an aquatic climax ecosystem. Along with the plankton, some weeds like Sargasso weed and agua mala are also quoted in certain parts of the text. Thus, Hemingway stresses the point that the plants are also a component in an aquatic climax ecosystem in the sea. The writer also pictures some birds that cross over the sea in this novel. At one point, Santiago seeks the help of a man-of-war bird to trace the existence of fish. There is also a description of a bird that rests on the line in which the marlin is hooked. Even when the old man enters the sea to begin his epic journey, he thinks of the delicate nature of birds in spite of which they withstand the harshness of the sea.

Tracing Behavioural Patterns: Animal characteristics and habits are also cited in this text. For instance, the old man could hear two porpoise rolling and blowing. He can even tell the difference between the rolling noise of the female and that of the male. Santiago also mentions that these porpoise will play and love each other making jokes. In one of his dreams, he sees a big school of porpoise and the porpoise were leaping "high into the air and return into the same hole they had made in the water when 
they leaped" (Hemingway 80). The nature of man-of-war bird has also been portrayed in this novel. The bird was encircling over the sea constantly and moving up and down at a regular pace. Santiago could notice the bird suddenly lowering down to the level of the sea parallel when the flying fish were spurting out of water and swim over the surface indicating the presence of dolphin beneath them. By seeing the flying fish, the bird slanted its wings and dived once again attempting to catch the flying fish even though the bird had no chance.

After hooking the marlin, the old man expects it to jump and he also states that if it jumps, the sacs along its back will be filled with air which will prevent the marlin from going deep into the sea. There is a description about sucking fish in which the sucking fish swam around the marlin. They are about three feet long and sometimes swim in the shadow of the marlin and sometimes found attached to the marlin. The natural behaviour of shark is also pictured in this novel. After the old man hooked the marlin, it is explained that a shark jumped out of water in the sun and it could smell the scent of marlin's blood and trace the course of the skiff of the old man. The sense of smell of the shark has been portrayed through these lines by the author in a precise manner. Description of animal structures can be found in a number of places in this novel. When Santiago sees the marlin swimming just near his skiff, it is described that, It was higher than a big scythe blade and a very pale lavender above the dark blue water. It raked back and as the fish swam just below the surface the old man could see his huge bulk and the purple stripes that banded him. His dorsal fin was down and his huge pectorals were spread wide. (Hemingway 89).

Description about dolphin can also be found. The old man conveys that a dolphin will look green from above and he has noticed it when he was travelling through a turtle boat. One can see stripes and purple spots on its body surface. If a dolphin is hungry, purple stripes can be seen on its sides. Hemingway also describes Mako shark in this novel in a detailed manner stating that the very appearance of the shark resembles that it is more powerful than any other fish in the sea. Except the jaws, all other things of the shark look beautiful and similar to the marlin. All the teeth that are similar to the fingers were pointed toward the interior with sharp edges. It is blue back and its sides are silver in colour. The structure of the shark is framed in such a manner that it can swim faster.

Irony In The Old Man And The Sea: It can be mentioned that the old man in the novel is well versed with the behaviour of animals. Santiago is portrayed as a great man who possesses all abilities to fight the odds of life. He has years of experience as a fisherman who can tackle all kinds of situations that may prevail in the ocean. His capacity to handle large fish and bad weather is also expressed by Hemingway in numerous places. Manolin also briefs about the strengths of Santiago on many occasions. Santiago's remembrance of some specific incidents that happened in the past also pictures his strength and competence. There are various descriptions in the novel representing the old man's knowledge of marine life and behaviour of varieties of fish under different circumstances. He also comprehends the incomprehensible situations that prevail inside the ocean. His understanding about different fishing equipment is far ahead of any other fishermen in his region.

Fishing is nothing new to Santiago. He has fished for years and knows almost everything about fishing and marine life. He is even able to predict the weather condition that may prevail for the next few days in the ocean. With his sound knowledge, he is able to identify the pros and cons of a situation beforehand and prevent the danger. He is also able to predict the water current in the ocean which will help sailing. He has great awareness about the other living and non-living things that can be seen in the sea. He sees yellow Gulf weed and briefs it is poisonous to human beings. He adds that shrimps can be seen dwelling in this weed. His knowledge about fish is unique. He can identify any type of fish just by glancing at it and predict its behaviour. His familiarity about different species of fish can be cited throughout the novel. He describes numerous varieties of fish that come across his skiff including their body structures and the taste of their flesh.

By hearing the noise of porpoise, he is able to tell the difference between the sound made by the male and the female. He also knows about the behaviour of different types of fish. He confirms it by stating that the marlin will jump in the air, and if it jumps, the sacs in its back will be filled with air and it will prevent it from going deep into the water. He also adds that this will be the behaviour of all fish types that have been hooked. He also has a definite idea about the place in which abundant fish can be found in the sea and proves it to be correct by mentioning the varieties of fish that can be found in a particular region which is deeper than the other parts of the ocean. He also comments on the behaviour of birds that cross the sea thereby proving that his knowledge is far beyond marine life.

With all his knowledge about ocean and marine life, Santiago shows some reluctance in his approach to fish the giant marlin. He regrets for not having the boy with him to manage the huge one. Portrayal of his regret now and then by Hemingway may be taken as an indication of the imminent defeat of the old man. His regret not only stops with Manolin, but also proceeds to a number of things such as salt, lime, weapon, fishing line, stone for sharpening the weapon, radio, for having gone so far into the sea, etc. This can be clearly identified in the lines "I wish it had been a dream now and that I had never hooked the fish and was alone in bed on the newspapers" (Hemingway 103). Santiago also remembers some regretful incidents that happened during his young age.

One example of which is that he states, "I never had anything wrong with my heel except the time the sting ray stung it when I stepped on him when swimming and 
paralyzed the lower leg and made the unbearable pain" (Hemingway 104). These regrets of Santiago reflect the loss of confidence in him and the confused state of his mind. All his efforts are in vain by his mistake of sailing too far into the sea for which he pays a huge price in the form of marlin and states that "I shouldn't have gone out so far" (Hemingway 110). He is even not ready to look at the damaged marlin at one point of time. All the dignity of the old man is ruined by a ridiculous mistake made by him. The message that no one has the right to cross the boundary of a climax ecosystem has been pictured clearly by Hemingway in this novel.

\section{CONCLUSION}

There is an inherent irony in Hemingway's conclusion towards the end of the novel through the lines "A man can be destroyed but not defeated" (103). The whole plot of the novel is only about the defeat of an old man, beyond all his skills, who went too far inside the sea for fishing. Santiago is defeated in this context and not destroyed. There are so many critics who try to justify that this statement of the author is true, but one can deduce the fact that in this novel man is not destroyed but defeated. An ecocritical perspective brings out the irony in these words of Hemingway. All the critics are only trying to presume what the author would have thought and this statement of the author being an irony will explain clearly the intention of the author. The complete concept of the novel can be well understood in this single line if the irony in Hemingway's tone is understood.

\section{REFERENCES}

Bloom, H. (Ed.). (2008). Ernest Hemingway's The Old Man and the Sea. Infobase Publishing.

Branch, M. P., \& Slovic, S. (Eds.). (2003). Kern, Robert. "Ecocriticism: What Is It Good For?" The isle reader: Ecocriticism, 1993-2003. University of Georgia Press. pp. 258- 281.
Brenner, G. (1991). The Old Man and the Sea: Story of a Common Man.

Burhans, C. S. (1960). The Old Man and the Sea: Hemingway's Tragic Vision of Man. American Literature, 31(4), 446-455.

Glotfelty, C., \& Fromm, H. (Eds.). (1996). The Ecocriticism Reader: Landmarks in Literary Ecology. University of Georgia Press.

Hemingway, Ernest. (1995). The Old Man and the Sea. Surjeet Publishers.

Love, G. A. (2003). Practical ecocriticism: Literature, biology, and the environment. University of Virginia Press.

Mohanraj, S. G. (2018). Ecological Connotations in The Old Man and the Sea and He Conquered the Jungle. International Journal of Pure and Applied Mathematics, 119(18), 3577-3585.

Mohanraj, S. G. (2020). Poetics of Ecological Wisdom: An Overview of WS Merwin's Creature Celebration Poems. Language \& Literature, 157.

Mohanraj, S. G., \& Sreejana, S. (2018). Egalitarian Worldview: The Fundamental Deliberation of Nature in the Poems of WS Merwin. Language in India, 18(1).

Sreejana, S., Vijay, A. L., \& Mohanraj, S. G. (2018). Demographic Analysis of Students and Inclination to Reading Skills. International Journal of English: Literature, Language \&t Skills, 2278, 0742.

Stephens, G., \&t Cools, J. (2013). "Out too far”: half-fish, beaten men, and the tenor of masculine grace in The Old Man and the Sea. The Hemingway Review, 32(2), 77-94.

Vijay, B. A. L., \& Mohanraj, S. G. (2018). The Shifting Stand-A Shift in Primitive Values in William Faulkner's Go down, Moses. Language in India, 18(5).

Yan, Y. U. (2011). The Call of the Wild - An Eco-critical Reading of The Old Man and the Sea. Canadian Social Science, 7(3), 167-175. 